(C) B.Л. Бигуаa

\title{
ОТГОЛОСКИ РОДОВОГО КУЛЬТА У АБХАЗОВ: МОЛЕНИЕ ХАРАНИЕВЦЕВ
}

\begin{abstract}
На основе нового полевого этнологического материала, собранного автором, в работе дается описание и интерпретация религиозного культа одного из абхазских родовых сообществ, хронологические рамки которого охватывают последние три столетия. Возникновение культа связано с чрезвычайным, но вместе с тем интересным обстоятельством, прочзошедшим в жизни родоначальника группы верующих, ежегодно совершающих моление Богу с «кровавым жертвоприношением». Культ представляет собой порождение традиционной религии абхазского народа Анщ̧әахайара (anc ${ }^{\circ}$ axaçara) - «вера в бога».
\end{abstract}

Ключевые слова: религия, культ, моление, бог, родовое божество, ритуал, жертвоприношение, патронимия

\section{Исторический аспект}

Несмотря на современные глобализационные процессы, охватывающие все сферы жизни человечества, многие народы сохраняют специфику своих традиционных культур и сегодня. К категории таковых относятся и абхазы. В частности, одним из компонентов их сегодняшней духовной жизни являются автохтонные религиозные представления, важным элементом остается система родовых культов. «По убеждению абхазов, - писал Н.С. Джанашиа, - бог един, но множественен в долях. Как каждое явление природы, так точно каждый род, каждая семья или личность имеет свою долю бога» (Джанашиа 1960: 22). Рассмотрим это на примере функционирующего ныне культа рода (фамилии) Хараниа (Harania) ${ }^{1}$.

На современной территории Абхазии первоначальным местом проживания рода Хараниа считается село Джгярда. По сути, в настоящее время он представляет собой немногочисленную патронимическую группу семей, насчитывающую около двадцати фамильных единиц. С течением времени, или волею судьбы, в подавляющем большинстве своем Хараниевцы обосновались в ряде других населенных пунктах страны, главным образом в ее столице - Сухуме. За рубежом их однофамильцы живут в Турецкой республике: в шести селах и двух городах - Стамбуле и Адапазаре.

Бигуаа Валерий Левардович - доктор исторических наук, ведущий научный сотрудник Института гуманитарных исследований имени Д. Гулиа АН Абхазии, профессор Абхазского государственного университета (Абхазия, Сухум, ул. Симона Басария, 3). Эл. почта: valera.biguaa@ yandex.kom. Biguaa Valery - Abkhaz Institute for Humanitarian Studies Gulia (Abkhazia, Sukhum, Simon Basaria street, 3). E-mail: valera.biguaa@yandex.kom

${ }^{1}$ В соответствии с закономерностью развития абхазских антропонимических моделей, исконное имя рода Harania - Haran, a ia - чуждый для них антропонимический формант, наращенный волею исторической судьбы. 
Между тем, согласно преданию, предок этого рода прибыл в село Джгярда, двести пятьдесят-триста лет тому назад. Информанты рассказывают об этом так: «С незапамятных времен многочисленный род Харан $(u a)$ жил недалеко от урочища Губаадвы (гәбаaдәы $/ \mathrm{g}^{\mathrm{o}} \mathrm{baad}^{\circ}$ ə), которое ныне называется Красная поляна (окрестность г. Сочи). Один из молодых людей это рода полюбил девушку по фамилии Хьац(иа), которая испытывала к нему взаимные чувства. Однако родители и особенно братья девушки были категорически против их брака. И юноша, убедившись, что в родной деревне не будет шанса создать семью, тайно бросился вместе со своей возлюбленной в бегство. Несколько дней и ночей они брели по тропам, пролегавшим по многочисленным ущельям и перевалам, пересекали русла бурных рек. В конце концов молодая пара оказалась в Джгярдинской общине, владетелем которой был князь из рода Маршан. Но молодые люди навестили не князя, а дворянина по фамилии Арютаа (Арыєтаа), который приютил молодых, предоставив им небольшой земельный участок для постройки жилища. Обосновавшись на новом месте и крепко встав на ноги, они щедро отблагодарили своего хозяина и, более того, купили у него довольно большую площадь земли» (ПМА: со слов Вл. Хараниа).

Личное имя родоначальника джгердинских Хараниевцев в их исторической памяти не сохранилось. Но до недавнего времени односельчане называли его не только по фамилии, но еще и параллельным именем - Гяджьипцва (Гьаџьипуцәа) «сыновья Гяджьа», которое, по всей видимости, следует понимать, как эпоним рода - Гяджипа. С тех далеких времен сменилось порядка двух-трех десятков поколений. Однако представители старшего поколения помнят только имена «своих больших отцов» ( $p a-$ бацуәадуқəа): Леуа, Хаджарат (хацьарат), Хындыгу (хындыгə), Кублыху (қәыбльхә).

Что касается турецких сородичей, то известно обстоятельство, по которому они оказались на чужбине. «В период второй большой волны депортации абхазского населения силами штыков Российских военных подразделений (1867), осуществлявшейся после небезызвестного Лыхнынского народного восстания, весь хараниевский род, насчитывавший тридцать четыре семейства, был подвергнут выселению. Вместе с другими, они насильственно были посажены на корабль, но когда судно отчалило, один из «пассажиров» бросился в море и приплыл к берегу. Вооруженные моряки открыли огонь, но чудом в него не попали. А на берегу беглец притворился мертвым. Смельчаком оказался Хараниа Хындыгу. Его не искали и после того, как корабль удалился, Хандыгу устремился к семье. За несколько дней до этих событий его жена вместе с сыном отправилась в гости в отчий дом, к родителям, проживавшим в соседнем селе Кутол. Хындыгу нашел жену и ребенка, которых благополучно доставил в собственный дом» (ПМА: со слов Вл. Хараниа.). Как раз джгярдинские хараниевцы и есть потомки этого отчаянного героя.

\section{Ареал распространения культа}

Сегодня хараниевский культ Аныханыхәа (anəxanəha) справляется лишь небольшой патронимической группой семей Владимира Львовича, Аполлона Львовича, Сатбея Шотаевича, Сафарбея Шотаевича и Салумана Шотаевича. В родственной связи все семьи состоят по латеральной линии, а каждая из них, как правило, - по восходящей и нисходящей. 


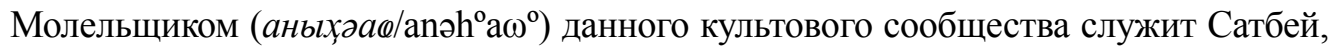
«получивший в руки ритуальную свечу» (аныхәа ацәашьхәы знапы иаку ауюы) после смерти своего отца Шоты. В свое время Шота получил ритуальную свечу также после смерти отца Леуа, последний - после смерти своего отца Хаджарата, Хаджарат - после смерти своего отца Хындыгу, того самого смельчака, который выпрыгнул в море с палубы корабля, и, добравшись до отчего дома, вновь зажег огонь в его потухшем очаге. До Хандыгу родовой свечой обладал Кублыху - им ограничивается способность нынешних представителей рода Хараниа перечислять имена своих предков.

В совершении ритуальных действ родового культа участие принимают все семьи данной патронимии, члены которых так или иначе склонны верить в сверхъестественные силы, независимо от христианской религии, приверженцами которой они себя считают на официальном уровне. Исключение - Аполлон Львович, по мнению которого родовой культ является анахроническим представлением сородичей о религии.

Согласно утверждению джгердинских Хараниевцев, потомки тех братьев, которым суждено было оказаться в заморской стране, не имеют уже представления о культе своих предков (ПМА: со слов Хараниа Вл.). С одной стороны, в потере памяти о нем сыграло свою роль время, с другой - ислам, который отцы нынешнего поколения рода исповедовали, тем более в Турции.

Культовая практика. Местом культового моления является «отчее гнездо» молельщика, Сатбея, находящееся в целости и сохранности недалеко от центра села Джгярда. Сам Сатбей со своей семьей живет и работает в Сухуме, но, как правило, в каждые выходные дни бывает в отцовском доме, присматривает за хозяйством и по силе возможности поддерживает его.

Культ состоит из двух составляющих, отличающихся друг от друга, с одной стороны, сроками отправления молитвы и произносимыми сакральными формулами, и разностью жертвенной пищи - с другой.

a) Первым по очереди является так называемое «уведомительное моление» (aеęmapa/aḉবатара). Оно совершается в среду перед праздником Пасхи (Aмmaņb/ amšðарә). Утром, после восхода солнца из-за гор, старшая в доме женщина - мать, бабушка - ставит у очага, в котором непрерывно горит огонь, традиционный глиняный горшочек акуджял (akəыцььал) полный воды с «фасолью для варки ее «по-абхазски» (akəыd апзсыуала ичап̧аны)» ${ }^{1}$, с тем расчетом, что блюдо достанется всем, кто должен принять участие в совершении ритуального моления Богу. Перед началом процесса приготовления она произносит слова благодарности Всевышнему: «Великий Бог, да обойти мне вокруг твоих золотых стоп! Дай нам тепло своих очей! Спасибо, что ты дал возможность нам встать у твоих ног и молить тебя о твоей

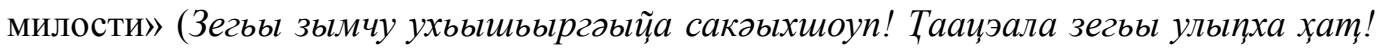

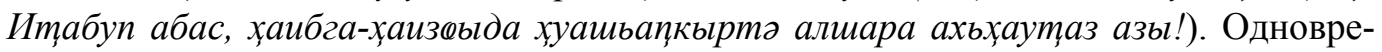
менно в котле варятся также семь грушеобразных лепешек из пшеничной муки, начиненных сычужным сыром, в очаге на сковороде пекутся два пирога, начиненные тем же сыром. Один пирог напоминает солнце, другой - молодую луну. В процессе приготовления пищи старшая непосредственного участия не принимает, в основном управляя помогающими ей молодыми женщинами.

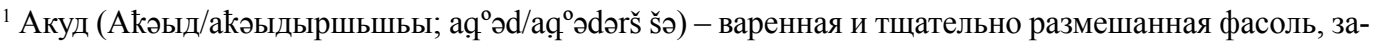
правленная небезызвестной аджикой. Перед употреблением его заправляю еще мелко нарезанной зеленью: луком, кориандром, сельдереем (см.: Трджман-ипа 2012: 188; Бигуаа 2012: 228).
} 
Моление совершается в молельне аныхварта (аныхқәарт̧а/anəhํarta). Это предназначенное для культа помещение представляет собой небольшую двускатную постройку, расположенную недалеко от жилого дома, за оградой двора. Под крышей на земляном полу стоит очищенный от коры небольшой дубовый чурбан, на котором красуется «тройка» (ахнапык) имитационных инструментов кузнеца - наковальня, молоток и щипцы (апсынгыыры, ажьахәа, арытәа). За чурбаном зарыты два кувшина, которые ежегодно хозяин заполняет черным вином и тщательно закупоривает ${ }^{1}$. В неурожайные времена он может собрать столько винограда, сколько необходимо для заполнения двух бутылок, которые по одной кладет в каждый кувшин и наглухо закроет их крышками. Один из кувшинов распечатывается во время отправления первоочередного моления.

В молении принимает участие только мужская половина семьи. Женщины к нему не допускаются. Они имеют право исключительно на приготовление мучной жертвенной пищи. Присутствие представителей других долевых семей возможно, но необязательно. Церемония начинается к вечеру, после захода солнца. Войдя в молельню, молельщик становится у культового кувшина. Перед молельщиком стоит стол, на который одним из взрослых членов семьи заранее кладутся в большую деревянную миску (acaара) вышеуказанные лепешки и пироги (фасоль к месту культа не подносится). Обратившись лицом к небу, где в то время показывается, или может показаться, луна, и взяв в правую руку зажженную свечу, молельщик отправляет божеству моление $a x$ ныххвара (aхныхқəара/axnəh ${ }^{\circ}$ ara). В данном случае он молится не столько за культовое сообщество, сколько за себя как лицо, представляющее его перед Богом, чтобы быть в форме в день праздника: - «Наверху находящийся Великий Бог, да обойти мне вокруг твоих золотых стоп! Сегодняшний день - день культа нашего рода, охватывающего потомство общего предка. Как тебе, моему повелителю, известно, я являюсь обладателем культовой свечи. Поэтому стою у твоих ног, захватив с собой ту пищу, которая тебе предназначена. Пока не прошел постный период времени, потому так скромно 2 . Прошу тебя, дай мне силу и веселое настроение, чтобы я смог встретить тебя достойно, на высоте. Через неделю после Великого праздника (Пасхи /Амшапы - В.Б.) я покажу тебе жертвенное животное, сначала в живом виде, затем - его сердце и печень»

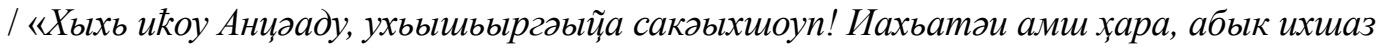
Ахуараниақља, хуныха иамшуп. Уара, сызкәвхшоу, ищудыруа еипиш, сабшьтра иайанакуа ауаапусыра зегьы рныха ащзашьхәы сара искуп.Убри акынтә сааины ушьапаеєь

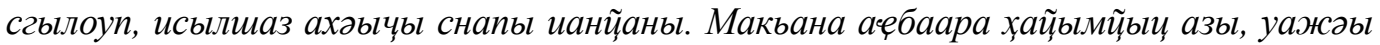

\footnotetext{
${ }^{1}$ Красное вино абхазы называют черным, поскольку чистое виноградное сусло из абхазских эндемичных сортов винограда имеет темный оттенок, и в народе ценится больше.

2 По абхазскому обычаю, пост - аеббаара соблюдается только в светлое время дня. С целью скрыть от Бога сою невыдержанность, ели утром до рассвета и вечером после захода солнца, но лишь блюда растительного происхождения, главным образом хлеб ели, мамалыгу с фасолью различного приготовления и прочими постными блюдами (ачгьахьа). Мясо-молочные продукты питания исключались. Но пост как таковой не распространяется на детей. Что касается исторических корней самого поста, то, вероятно, они уходят к тем временам, когда недостаток продуктов питания, что ощущался уже к весне, требовал самоограничения в еде, и со временем эти ограничения получили форму запретов, узаконенных обычаем. Свидетельство тому - отраслевая лексика абхазского языка, связанная с постом: аеєбаара, ачгара, ачгахьа, что означают «пост», «поститься», «постная пища» соответственно. Буквальный перевод первого термина звучит как «гниение уста», последующих два - «отодвигать хлеб от себя» и «постная доля». Оба последних термина являются производными от названия хлеба - «ача», древнейшего продукта питания абхазов. О термине «ача» см.: Инал-ипа 1965: 236; Бигуаа 2018: 96).
} 


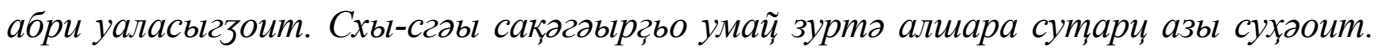
Пизала иааиуа аныхудаду ашәны, сабипуара иатәу ахаџәарпуар насыдыргыланы, уара иузку хуныхудагатә абзареи агәи-агәайәеи усырбоит!

Завершив молитву, молельщик три раза обводит вокруг своей головы свечу и прикрепляет ее к переднему опорному столбу постройки. Затем снимает крышку с культового кувшина, вычерпывает из него стакан черного вина и, произносит ту же формулу молитвы. Отпивает не спеша, как бы оценивая вкусовые качества вина, дает попробовать его и другим смиренно стоящим за ним домочадцам, и наблюдающим за тем, как молельщик говорит и действует. Затем возвращается домой и приступает к трапезе вместе с членами семьи.

Мучным блюдом служат исключительно культовые лепешки. Отдельно, в другом котле варят еще значительное количество лепешек наподобие первых, но они не несут ритуальных коннотаций и предназначены просто для ужина. Фасоль - символ поста подается по желанию. Культовое вино воспринимается как обязательная принадлежность торжественного стола. Присутствующие произносят традиционные тосты, но молельщик воздерживается от них, поскольку уже имел честь общаться с Богом. Между тем никто не вправе выказывать при этом даже слабые признаки опьянения.

б) В соответствии с уведомлением молельщика, второе - основное моление

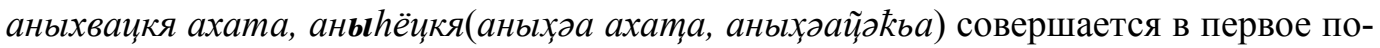
слепасхальное воскресенье - т.н. женскую Пасху (Ахуәса рымшап̆ы). Как свидетельствуют старшие представители культового сообщества, в старину моление совершалось прямо в день Пасхи (Aмшапуы), но, учитывая, что каждый человек отмечает этот великий праздник в сугубо семейной обстановке, отрывать его от дома не совсем гуманно. Еще дед Леуа перенес моление на женскую Пасху, безусловно, сделав при этом подарок божеству - в виде преподношения годовалого козленка, которого заколол, строго соблюдая все процедуры, связанные с молением.

Сегодня родовой молельщик - Сатбей, старший сын Шоты Хараниа, ставший обладателем «доли культовой свечи» (ашжәлантә ризашьхәы зку ауаєы) после смерти отца. Правда, ему всего лишь 59 лет - по абхазской стратификации он молодой, но соционормативная традиция абхазов «старшинства-младшинства» (аихуабреийыбра) - налагает на него обязанность «посредника между богом и соплеменниками» (анцәеи ауааи ирыбжьагылоу ауюы).

В день основного культового праздника, молельщик поднимается раньше всех в семье, еще и потому, что является старшим мужчиной, «нога» которого считается самой счастливой. Он моется, надевает на себя свежую одежду, которая, как полагается жрецу, светлого цвета. Домочадцы-мужчины помогают ему во всех начинаниях: разведении огня в очаге, обеспечение дровами, выгоне культового животного и др. Слабая половина семейства приступает к «женским делам» (апхәысус) ${ }^{1}$ : наведению должного порядка в доме и во дворе, подготовка посуды, необходимой при приготовлении пищи.

Культовое животное представляет собой годовалого козленка белого цвета, без какого-либо изъяна - холощенного или того, который не успел еще спариться с козочками (ахьақљла).

\footnotetext{
${ }^{1}$ В хозяйственно-бытовой жизни абхазов существует традиция половозрастного разделения труда, отличающаяся известной гуманностью характера. Относительно легкие домашние работы (внутренние) называются «женские дела» (апхәысус), а внешние, то есть полевые, требующие большую физическую силу - «мужскими делами» (ахацаус). Параллельно разделяются дела также на взрослые и детские работа, которые обозначаются терминами: аду иус, ахәычы иус (Бигуаа 2010: 44).
} 
Остальные члены культового сообщества съезжаются к полудню. Главы всех семей доставляют хозяину свою «долю расхода» амартхв (амартухә/amartx $\left.{ }^{\circ}\right)$, связанную с проведением моления, начиная с культового животного (ambməbl/ašt $\left.{ }^{\circ} ә\right)$, кончая кусочком воска, из которого делают культовую свечу (au̧əaщbbl/ac ${ }^{\circ}$ ašə). Отметим, что еще в недалеком прошлом, за исключением козленка, все виды амартхв доставляли в натуре, сейчас - в денежном выражении. В дальнейшем все трудоспособные члены культового сообщества, особенно молодые, помогают хозяевам сего дома во всех культовых приготовлениях и накрытии праздничного стола.

К полудню мужская часть культового сообщества собирается посередине просторного двора дома. Молельщик приступает к совершению абзарарбара (моление живым культовым животным). Жертвенному козленку производят ритуальное омовение мордашки и ножек. Затем, взяв жертвенного козленка за рог и обратившись лицом к восходу солнца, он произносит культовую молитву: «для нас, Хараниевцев, происходящих от одного общего предка, сегодняшний день - большой день, праздничный день, он день «нашей доли аныха», праздник, идущий от моего отца, деда, от его далеких отцов. И мы встречаем и проводим этот праздник так же, как нам показали они. Великий Бог, да обойти мне вокруг твоих золотых стоп! Все мои сородичи, являющиеся подданными нашего культа, стоят за моей спиной. Просим твою милость. Дай нам тепло своих очей и твоего сердца! Дай нам доброго здоровья так, чтобы ни у кого из нас не болела голова, не болело сердце, береги того, кто дома, кто вне дома, и млад, и стар, где бы ни были, береги от несчастного случая, сохрани всех нас в целости. Да чтоб на твои глаза попадалось только добро! Как видишь, наше жертвенное животное стоит тут. Сейчас я покажу тебе его в живом виде, чуть позже покажу - его сердце и печень» / Хара, абипуарак иатәу Ахуараниақља, хззь иахьатәи ами мышдууп, ныхуәамшуп. Хныхахә иамшуп. Саб, сабду, уи иабацуадуқуа

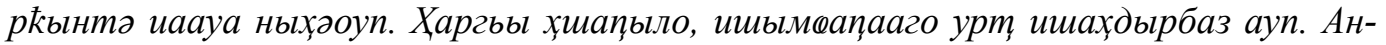

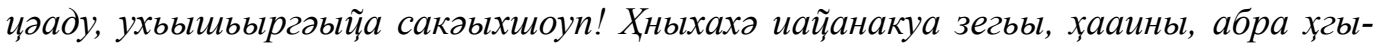

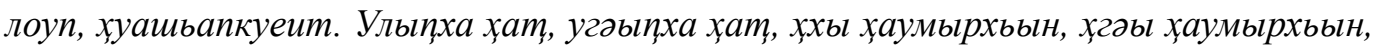
аєны коу дыхьча, адәаы икоу дыхьча, дхәычума, ддуума, иахьыказаалакь. амашәыр ркәыблаа. Хаигумырхан! Ула абзиа абааит(!), хуныхудагатә абра ићоуп. Уажәы уи абзара усырбоит, ушьтуан агәи агәайдеи усырбоит

Закончив молитву, молельщик трижды поворачивает животное в полный поворот. Делает такие же полные повороты и сам. Вслед за ним повороты совершают все остальные участники моления. Молельщик делает поклон божеству.

Двое из числа молодых людей помогают ему повалить жертвенное животное на землю головой на восток, но лицом на юг, «чтобы божеству было видно его хорошо, чтобы убедился в достоверности действа». Прижав правым коленом к земле, молельщик закалывает животное резанием горлышка. Затем рану очищают огнем горящей головешки, после чего тушу подвешивают за правую ногу на дереве и начинают свежевание. После удаления потрохов, тушу разделывают на части. Мясо варят на открытом огне, специально разожженном под открытым небом ${ }^{1}$.

Есть еще одна деталь культового действия, обычная в церемонии жертвенного подношения богу. Шкуру убиенного козленка заворачивают и кладут высоко на де-

\footnotetext{
${ }^{1}$ Согласно религиозным представлениям абхазов, варить культовое мясо в доме, закрытом от неба помещении, не полагается. Божество должно быть в курсе воочию того, что делается человеком, совершающему ему моление.
} 
рево, чтобы она не упала и ее не смогли достать собаки. Позже шкуру просаливают и, растянув на прутьях, сушат на солнце. Копыта козленка аккуратно закапывают, рога вывешивают на стене культовой постройки. Небрежное обращение даже с отходами туши не допускается, так как оно может вызвать недовольство Бога, в честь которого было совершено само религиозное предприятие.

Как только сварится мясо и необходимое количество ритуальных лепешек, описанных выше, испечены, совершается и вторая очередь моления, но уже в помещении культовой постройки. Ритуальную мучную пищу (семь грушеобразных лепешек и лепешки, напоминающие солнце и новую луну - «солнце» и «луна») доставляют в деревянной миске. Всю провизию ставят на стол, располагающийся между молельщиком и известными нам атрибутами постройки - набором железных инструментов и винными кувшинами. Молельщик, сняв головной убор, становится посередине помещения лицом к «тройке инструментов». В левой руке он держит заостренную фундуковую палочку арасацъвы (apacaųəы), на которую нанизаны сердце и печень убиенного жертвенного козленка, а также «солнце» и «луна» ${ }^{1}$. Правой рукой молельщик берет стакан вина, вычерпнутого им из упомянутого выше специального кувшина, который должен открываться исключительно в день главного культового моления.

Затем молельщик почти один в один повторяет ту же молитвенную речь, которую говорил при поднесении жертвенного животного, но сейчас также сообщает Богу о том, что он сдержал слово, показывая ему сердце и печень жертвенного животного. Во время молитвы позади молельщика стоит та же группа культовых подданных и тетя (сестра отца) молельщика со своей внучкой, имеющая право присутствовать здесь как старшая, как «чистая женщина» ${ }^{2}$. Другая женская половина культового сообщества тоже слушает молитвенную речь молельщика, но стоя за пределами молельни.

После завершения молитвы все вслед за молельщиком делают ритуальные повороты. Затем молельщик пригубляет вино и закусывает ломтиками сердца и печени, производит ритуальное обливание капельками вина пищевых ломтиков. Кусочками ритуальной пищи он угощает всех участников культа. После этого молельщик зажигает свечу, обводит ее вокруг «клумба», образованного головами участников религиозной церемонии и прикрепляет ее к передней опоре постройки. Этим актом завершается весь набор ритуальных действ.

Праздничное застолье. Финал родового празднества - веселое застолье, богатое не только ритуальной пищей, но и всевозможными блюдами, как домашнего приготовления, так и покупного. При проведении застолья соблюдается половозрастная градация: мужчины садятся за предназначенным им отдельным столом, вытянутым в правой половине помещения, женщины - за другим столом, что стоит в левой стороне. Старший член рода, коим в данном случае является дядя молельщика - Владимир Хараниа, провозглашает первый тост: «Бог, дай нам тепло своих очей» (Анц̧әа yлып̧ха х̧ат!!). Он же избирает тамаду из числа приглашенных соседей; все присутствующие за столом выпивают стакан за его здоровье. Тамада благодарит старшего, назвавшего его кандидатуру на «пост» тамады, а также и всех поддержавших и пожелавших ему добра, и в свою очередь, предлагает тост за здоровье хозяина,

\footnotetext{
1 Заостренная палочка, на которую нанизываются сердце и печень, изготавливают из фундукового прута, так как, по народному поверью, фундук счастливое дерево, оно даже не подвергается удару молнии.

2 «Чистая женщина» - женщина, перевалившая менструальный возраст.
} 
являющегося одновременно молельщиком. Естественно, тост подхватывается, все стоя поднимают стаканы с вином. Между тем сам молельщик ведет себя как бы застенчиво, пассивно принимая участие в проведении праздничного стола, поскольку его общение с Богом уже состоялось.

В дальнейшем застолье идет своим чередом с соблюдением порядка произнесения традиционных застольных тостов. Женщины при провозглашении тамадой тоста за ту или иную персоналию, как и мужчины, поддерживают его вставанием со стаканами на руке, выпивая несколько глотков или, скорее, ограничивались легким прикосновением губами к краю стаканов.

Важно отметить, что во время культового праздника традиционный застольный этикет соблюдается строже, чем в обычное время. Видимо, всеми участниками культового празднества учитывается близость и повышенное внимание Всевышнего, который, по мнению народа, непреклонно одобряет устоявшийся порядок поведения людей.

\section{Опыт интерпретации этнографического материала}

Неудивительно, что хараниевцы не очень четко представляют происхождение культа, связывая его порой с другими объектами сакрального календаря абхазов. По мнению некоторых (ПМА: напр., Вл. Хараниа), их моление - это проявление традиционного у абхазов культа кузни и кузнечного дела Ажрныхва (Ажьырныхқәа) (ažərnəha) (Об этом культе см.: Аджинджал 1969: 215-275; Ардзинба 2015: 95-154; Бигуаа, 2018: 198-227), другие (ПМА: напр., Сф. Хараниа) говорят, что это культ

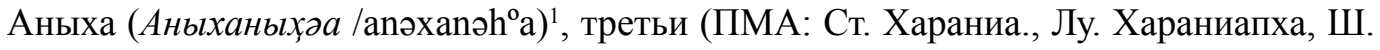
Хараниапха) вообще разводят руками: «Кто знает, что это за моление и как оно называется? Мы отправляем его Богу так, как показали наши отцы и деды. Единственное, что нам хорошо известно, это то, что моление это принадлежит нам и только нам». Этим объясняется и формула молитвенной речи молельщика, в которой слышится только Анц̧ва (Анц̧əа $\left./ \mathrm{anc}^{\mathrm{o}} \mathrm{a}\right)$ - имя верховного Бага, но не кого-либо другого конкретного божества/покровителя.

В «путанице» сказывается не только время, хронологические рамки которого охватывают несколько столетий, но и неимоверная сила культовой кузницы, покровителем которой является грозное божество Шяшвы (Шьaməbl/šašo $)$ ), занимающее значительное место в религиозной жизни абхазского народа. А грозность последнего объясняется его происхождением от еще более грозного, могучего Бога грома и молнии, $A \not b b l$, являющегося вторым после Верховного в иерархии богов Абхазского пантеона. Отсюда и наличие специальной культовой постройки, под крышей которой имеется основной набор атрибутов кузницы.

На самом деле этот культ совершают только джгердинские Хараниевцы, происходящие от ахчипсинского «беглеца», известного как Гяджипа, независимо от места их постоянного проживания. А те Хараниевцы, которые оказались в заморской стране, не знают о нем ничего.

\footnotetext{
${ }^{1}$ Аныха - святилище, по представлению абхазов обладающее большой сверхъестественной силой. Его происхождение связано с сакрализацией кузницы, обязанной в свою очередь метеоритному железу - «небесному камню» (афырхы), подарку от Бога грома и молнии, Афы. В хронологическом отношении возникновение объекта уходит своими корнями в глубину тысячелетий (подр.: Бигуаа 2018: 122-128).
} 
По логике вещей, описанное моление представляет собой отголосок традиционного у абхазов культа родовой доли Бога - Aнщвахвы $\left(\text { Анц̧әахәы } / \mathrm{anc}^{\mathrm{o}} \mathrm{ax}{ }^{\mathrm{o}}\right)^{1}$. Его основание было заложено обетом Гяджипа, принятым им по дороге, где он и его невеста могли столкнуться с множеством естественных барьеров, при преодолении которых они могли поплатиться жизнью. Судя по аналогичным примерам, сохранившимся до настоящего времени, формула обета могла звучать таким образом: «Могучая, Моя доля Бога, прошу тебя, покровительствуй! Сделай, чтобы Великий Бог ниспослал мне и невесте моей свой взор, спаси нас! Если мы дойдем до места назначения, то клянусь тобой, преподношу тебе козленка с белой мастью, в которой нет ни одного черного во-

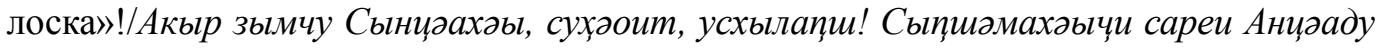

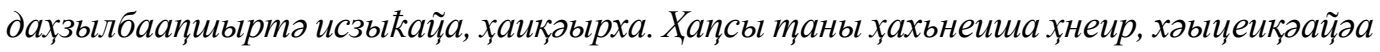
злам ахьақәла шуйаскуа азы туоуба зует! Еще бы! Путь молодоженов длился десятки дней и ночей, повторюсь, все они были полны неожиданных опасностей, какие только могут быть в предгорных тропах, идущих через многочисленные перевалы и темные широколиственные леса, где водятся различные кровожадные звери. Подтверждением всего этого служит предание, согласно которому «культ доставлен сюда, в Джгярда, самим родоначальником данного сообщества людей (абри аныхахә аазгаз иара хуабдузза иоуn)» (ПМА: со слов Вл. Хараниа, Сф. Хараниа, Ст. Хараниа).

По всей вероятности, с этими обстоятельствами связаны также жертвенные мучные блюда - «груша», «солнце» и «луна». Похоже, что последние две лепешки служат знаком благодарности жениха божествам двух главных небесных светил за свет, за тепло, которые так необходимы были ему и его невесте для выживания в условиях испытания жизни в дикой природе. Более того, абхазская космогоническая мифология говорит о том, что луна и солнце - жених и невеста (Джанашиа 1960: 29-30). Грушевидность первой лепешки показывает жизнь, берущую свое начало из соединения двух противоположностей. Верхний, острый конец ее символизирует мужскую силу, нижняя, плоская сторона - женское лоно. Количество лепешек также неслучайно: «семь» - самое сильное число сакрализации, которая имеет место в абхазском духовном быту. Оно обладает магической силой${ }^{2}$.

Не случаен также выбор жертвенного животного: Белый цвет - символ светлого дня, счастья и счастливой земной жизни.

Дата культового празднества наталкивает на мысль о том, что либо она совпала именно с днем празднования Пасхи (Амшап̧ы), либо с совершением первого ритуального моления. Другого объяснения нет и быть не может. Подтверждение тому табуированные, или запретные дни Амшшьара (amšðšara; дословно: «определение/ признание дня» с особой значимостью, особым статусом). Запретные дни соблюдаются членами рода и до настоящего времени по воскресеньям, особенно женщинами старшего поколения. В течение светового дня «запрета» мужчины не занимаются земляными работами, не вытачивают железные орудия труда, никому не выдают ничего в долг, а женщины не шьют, не спрягут, не стирают личные вещи, независимо от половой принадлежности, члены семьи не ходят на панихиду, похороны, помин-

\footnotetext{
${ }^{1}$ Согласно системе традиционной религии абхазов, все явления и объекты космоса/мира, природы имеют свои доли Бога (Анцәахәы). Свою долю Бога имеет и человек, как часть природы. Отсюда и родовая доля Бога» (См.: Джсанашиа 1960: 36-38; Чурсин 2019: 43-46; Инал-ипа 1965: 549; Бигуаа 2018: 52-53).

${ }^{2}$ Сакрализация числа «семь» характерна для культур всех древних народов мира. В абхазской же традиции она имеет особое значение см.: Бигуаа 2012: 208-209; 2019: 226-227.
} 
ки и другие события, связанные с печалью. То есть родовой культ и определенный для него день - две стороны одного явления, сопровождающегося массой элементов табу. Источник и того, и другого один - обет, принятый в критический момент жизни, в ситуации смертельного страха. К тому же, в прошлом абхазы имели обыкновение приурочивать культ Анц̧әахәы к празднику Aмmап̧ы (amšapə) ${ }^{1}$, как дню Нового года (См. об этом: Бигуаа 2019: 109-113). Отметим еще, что с течением времени высшее особое существо, по велению которого осталась в живых влюбленная пара, приобрело теонимическое лицо в форме родового покровителя, который затем получил святое нарицательное имя - Аныхаху ( связанное с ним, - Aныханыхуәа (anəxаnəhํa). Выражаясь словами Г.Ф. Чурсина, и сегодня не потеряло своего значения представление о том, что родовой покровитель неведомо присутствует всегда и везде в жизни каждого члена рода (Чурсин 2019: 44).

В заключении хочется отметить еще, что в период существования советской власти Хараниевский культ Aныххыныхқәа (anəхапәһa) отмечался нелегально или редко, и находился как бы на грани забвения. Сегодня культ этот занимает стабильное место в религиозной жизни всей родственной группы семей, не только как праздничное мероприятие или просто дань уважения памяти предков, уважение к традициям прошлого, но и как одно из важнейших идеологических начал, способствующих укреплению чувства единения людей, ежегодно совершающих данное моление. Очевидно, что родовой культ Хараниевцев будет иметь продолжение в дальнейшем

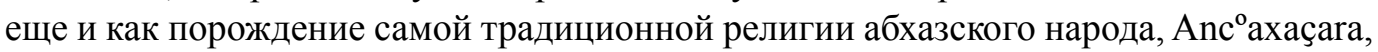
корни которой в его сознании живы и зарыты глубоко. Не последнее место в этом занимает и чувство гордости коллектива за своего родоначальника, образ которого поистине воспринимается им как символ решительного нахождения выхода из безвыходного положения, как символ героического поступка вообще.

\section{Источники и материалы}

ПМА: со слов Вл. Хараниа. - Хараниа Владимир Львович, 78 л., с. Пшап, зап. 5.05.2018. В более подробном варианте данная информация нашла свое отражение и в несколько позже увидевшей в свет его книге (Хараниа 2019: 161, 163-169).

ПМА: со слов Ст. Хараниа, СФ. Хараниа - Хараниа Сатбей Шотаевич, 59 лет; Хараниа Сафарбей Шотаевич, 54 года, с. Джгерда. Зап. 5.05.2019.

ПМА: напр., Вл. Храниа - Хараниа Владимир Льович. Зафиксировано в день отправления моления Богу - 5.05.2019.

ПМА: напр., СФ. Хараниа - Хараниа Сафарбей Шотаевич. Зафиксировано в день моления Богу -5.05 .2019 .

${ }_{1}^{1}$ «В это день (в день Пасхи/Амшапы - В.Б. ) большинство абхазов благоговейно совершает это моление богу («доле Бога» - В.Л.)... абхаз приносит жертву только тем богам, под власть которых подпали его родители или он сам лично, и тем, если так можно выразиться, он сделался данником их... и христиане, и магометане. В честь бога (Анцәахәы - В.Б.) у каждого абхаза (семьи - В.Б.)» в погребе имеется особый кувшин, который наполняется лучшим суслом. И какая бы страшная нужда ни досигла его дом, абхаза ни за какие блага не откроет «жертвенного» кувшина до совершения культа моления богу. Рано утром, по возвращении из церкви, глава семьи, окруженный всеми домочадцами мужского пола, над «жертвенным» кувшином закалывает козленка, просит великого бога милостиво принять смиренную «жертву», совершаемую ими, как учили отцы и деды... После этого варится мясо жертвенного козленка и пекутся жертвенные пироги из пшеничной муки. Все это приносится опять в погреб и ставится перед жертвенным кувшином. Молится...» (Джанашиа 1960: 36-38). 
ПМА: напр., Ст. Хараниа, ЛУ. Хараниапха - Хараниа Сатбей Шотаевич Хар, 59 л., Хараниапха Луля Львовна, 83 года, Хараниапха Шура Львовна, 81 год. Зафиксировано в день отправления моления Богу - 5.05.2019.

\section{Научная литература}

Аджинджал И.А. Из этнографии Абхазии. Сухуми: «Алашара», 1969.

Ардзинба В.Г. Собрание трудов. Т. III. М.-Сухум, 2015.

Бигуаа В.Л. Абхазская традиционная семья и действительность. Сухум, 2010.

Бигуаа В.Л. Вопросы традиционной религии и бытовой культуры абхазов. Сухум: «Алашарбага», 2012.

Бигуаа В.Л. Ритуальный мир традиционной религии абхазов. М.: Макс пресс, 2018.

Джанашиа Н.С. Статьи по этнографии Абхазии. Сухуми: Абхазское государственное издательство, 1960.

Инал-ипа Ш.Д. Абхазы. Сухуми: «Алашара», 1965.

Тарджман-ипа Г. Пища и домашняя утварь, застольный этикет // Абхазы. М.: Наука, 2012.

Хараниа В. Ахьышьтра амєала. Путь к истокам. Koklerin - Akəa, 2019.

Чурсин Г.Ф. Абхазы. Опыт этнологического исследования. Сухум: Akademia, 2019.

\section{References}

Adzhindzhal, I.A. 1969. Iz etnografii Abkhazii [From the ethnography of Abkhazia]. Sukhumi: "Alashara".

Ardzinba, V.G. 2015. Sobranie trudov [Collected Works]. Vol. III. Moscow; Sukhum.

Biguaa, V.L. 2018. Ritual'nyi mir traditsionnoi religii abkhazov [The ritual world of the traditional religion of the Abkhazians]. Moscow: "Maks press".

Biguaa, V.L. 2012. Voprosy traditsionnoi religii i bytovoi kul'tury abkhazov [Issues of traditional religion and everyday culture of Abkhazians]. Sukhum: "Alasharbaga".

Biguaa, V.L. 2010. Abkhazskaia traditsionnaia sem'ia i deistvitel'nost' [Abkhazian traditional family and reality]. Sukhum.

Chursin, G.F. 2019. Abkhazy. Opyt etnologicheskogo issledovaniia [Abkhazians. Experience of ethnological research]. Sukhum: Akademia.

Dzhanashia, N.S. 1960. Stat'i po etnografii Abkhazii [Articles on the ethnography of Abkhazia]. Sukhumi: Abkhazskoe gosudarstvennoe izdatel'stvo.

Inal-ipa, Sh.D. 1965. Abkhazy. [Abkhazians]. Sukhumi: "Alashara".

Kharaniia, V. 2019. Put' k istokam. [Path to the origins]. Sukhum.

Tardzhman-ipa, G. 2012. Pishcha i domashniaia utvar', zastol'nyi etiket [Food and household utensils, table etiquette]. In Abkhazy [Abkhazians], edited by V.A. Tishkov. Moscow: Nauka.

\section{Biguaa, Valery $L$.}

\section{Echoes of an Abkhazian ancestral cult: Anykhanykhua (anəxanəh $\left.{ }^{\circ} a\right)$ - $\operatorname{prayer}^{\circ}$ of the Kharaniia family}

The article gives a description and interpretation of a religious cult of one of the Abkhazian communities, the chronological framework of which covers the last three centuries. The study is based on new field ethnological material collected by the author. The cult originated in extraordinary, but at the same time interesting circumstances, which occurred in the life of the ancestor of people who annually pray to God with a "blood sacrifice". The cult is an offspring of the traditional religion of the Abkhazian people Antsakhatsara (anc axaçara) "faith in God".

Key words: religion, cult, prayer, god, tribal deity, patronymia 


\section{«ЗНАЮТ, ОПАСАЮТСЯ, НО НЕ ГОВОРЯТ»: КОЛДОВСТВО У ЗАКАВКАЗСКИХ ДУХОБОРЦЕВ*}

На основе полевого материала, собранного среди закавказских духобориев, в статье рассматривается «колдовской» дискурс, сформировавиийся в секте за два столетия, прожитые духобориами в отрыве от русского народа. Противоречие между народной традицией, которую они принесли из мест своего выхода, когда жили среди православньх в России, и религиозной доктриной, не допускавшей возможности общения сынов Божьих с нечистой силой, привело к тому, что тема колдовства была вынесена на периферию культурного поля и открыто не обсуждалась. В работе рассматриваются традиционные комплексы фольклорных сюжетов, дожившие в духоборческой среде до наших дней, и обращено внимание на широко известные сюжеты, оказавииеся неприемлемыли в их сообществе. Хотя среди духобориев не было людей, реально занимавиихся колдовскими практиками, в статье показаны механизмы «создания» образа колдуна. Потребность в таких людях исчерпывалась желанием односельчан возложить на них ответственность за проблемы и несчастья.

Ключевые слова: духобориы, религиозное учение, колдовство, фольклорный образ, русская мифологическая традииия

Начиная со второй половины XVIII в. ученые разных специальностей изучали представления русского народа о колдовстве и колдунах. С конца 1980-х годов, когда были сняты идеологические ограничения на подобную тематику, и до настоящего времени о колдунах и колдовстве написано и издано значительно больше литературы, чем за весь предшествующий период. Тем не менее, несмотря на многолетнее активное изучение, тема эта настолько многопланова, что заинтересованный исследователь всегда найдет в ней белые пятна, требующие его внимания. В данной работе речь пойдет о колдовстве и колдунах, об отношении к ним в религиозном

Иникова Светлана Александровна - кандидат исторических наук, ведущий научный сотрудник Института этнологии и антрополога РАН (Москва, Ленинский пр., 32a). Эл. почта: ovis2@yandex.ru. Inikova, Svetlana A. - Institute of Ethnology and Anthropology, RAS (Moscow, Leninsky prospect, 32a). E-mail: ovis2@yandex.ru

* Публикуется в соответствии с планом научно-исследовательских работ Института этнологии и антропологии РАН 